\title{
Status and economic valuation of ecosystem services of Tanguar haor: A wetland of Bangladesh
}

\section{H. M. Solayman, Md. Abdul Baten and Md. Badiuzzaman Khan}

Department of Environmental Science, Faculty of Agriculture, Bangladesh Agricultural University, Mymensingh-2202, Bangladesh

\begin{tabular}{|c|c|}
\hline ARTICLE INFO & Abstract \\
\hline $\begin{array}{l}\text { Article history: } \\
\text { Received: } 10 \text { June } 2018 \\
\text { Accepted: } 12 \text { August } 2018\end{array}$ & $\begin{array}{l}\text { Tanguar haor wetland is one of the listed Ramsar sites enrich with biodiversity variety and provides } \\
\text { several ecosystem services with significant contribution to the national economy of Bangladesh. But these } \\
\text { services were decreasing day by day due to natural and anthropogenic activities. The purposes of this } \\
\text { study were to identify the utilized ecosystem services by communities, economic values of utilized }\end{array}$ \\
\hline $\begin{array}{l}\text { Keywords: } \\
\text { Ecosystem services, economic } \\
\text { valuation, haor wetlands, water } \\
\text { quality, driving forces }\end{array}$ & $\begin{array}{l}\text { ecosystem services and the basic reasons for depleting of ecosystem services. Data were collected through } \\
\text { baseline survey, checklists, face to face questionnaire survey and focus group discussion (FGD) from } 120 \\
\text { residential respondents and } 50 \text { tourist respondents by accepting random sampling techniques during } \\
\text { November, } 2016 \text { to September, } 2017 \text {. Physiochemical characteristics of the water were determined where } \\
\text { the mean temperature and pH were } 28.26^{\circ} \mathrm{C} \text { and } 7.72 \text { respectively. The highest TDS, EC, DO, } \mathrm{NO}_{3} \text { and }\end{array}$ \\
\hline $\begin{array}{l}\text { Correspondence: } \\
\text { Md. Badiuzzaman Khan } \\
\text { (mbkhan@bau.edu.bd) }\end{array}$ & $\begin{array}{l}\mathrm{PO}_{4} \text { values were } 1020(\mathrm{mg} \mathrm{L}), 1460(\mu \mathrm{sm}), 8.56(\mathrm{mg} \mathrm{L}), 1.769(\mathrm{mg} \mathrm{L}) \text { and } 0.078(\mathrm{mg} \mathrm{L}) \text {, } \\
\text { respectively. Commonly utilized ecosystem services were crops, vegetables, fuel, fresh water, fishes and } \\
\text { relations, birds, climate regulation, water purification, natural hazards protection, aesthetic, social } \\
\text { for species and provision of habitat etc. Market Value Method (MVM) and Contingent Value Method } \\
(\mathrm{CVM}) \text { were applied to measure the economic value of Tanguar haor wetland services. DPSIR framework } \\
\text { and Impact Matrix (IM) were applied for conceptual analysis to identify the effects on ecosystem services. } \\
\text { Total economic value of } 39 \text { ecosystem services of Tanguar haor was estimated at } 174039980 \text { BDT year }{ }^{-1} \text {. } \\
\text { Mismanagement of biodiversity, over exploitation, sedimentation of haor, climate change, illegal hunting, } \\
\text { land use changes and habitat changes were the responsible factors for depleting ecosystem services. The } \\
\text { impact factor (4.161) was identified by natural and anthropogenic factors on ecosystem services. There } \\
\text { have a vast prospect of the Tanguar haor wetland services for near communities. Finally the research } \\
\text { suggested several sustainable management approaches which have the potentiality to protect the services } \\
\text { of the wetland. }\end{array}$ \\
\hline
\end{tabular}

\section{Introduction}

Wetlands are the world's most productive environment that supplies a broad collection of profit and keeping ecological balance of ecosystem (RCS, 2013; Islam et al., 2014) as well as essential to human wellbeing (Barbier et al., 1997; MEA, 2005). The significance of wetland is universal like ecosystem services. Ecosystem services are natural assets (Barbier, 2011) generated by the environment and exploited by human being, such as clean air, water, food, fuel and other materials. These services have high monetary value (Barbier et al., 1997) and contribute to social and cultural well-being (Fisher et al., 2009). Ecosystem services are the benefits obtained from ecosystem to human being (Costanza et al., 1997; Groot et al., 2002; MEA, 2005). Nature generally provides four types of ecosystem services (MEA, 2005) such as "provisioning" (e.g. food, timber, woods), "regulating" (e.g. climate regulation, disaster risk reduction, soil erosion control), "cultural" (e.g. aesthetic, spiritual, education, recreation, ecotourism) and "supporting" e.g. soil formation and retention, nutrient cycling, water cycling) services (MEA, 2005; TEEB, 2010; Groot et al., 2002).

Tanguar haor wetland is a freshwater wetland that offers social, economic and environmental benefits which helps community's livelihoods and creates income source (Khan, 1993). There have a significant economic and ecological importance on life and livelihoods of wetland ecosystem in Bangladesh (Kabir and Amin, 2006). Tanguar haor wetland provides food, fuel, fodder, genetic resources, flood regulation, hydrological services, aesthetic, spiritual, learning \& knowledge, recreational use, photosynthesis, primary production etc (IUCN, 2015). It has a great importance in fish production, maintaining biodiversity and living place of migratory birds. Though there have a vast prospect of the economic value of Tanguar haor wetland, economic valuation of the ecosystem services of the wetland was not done properly yet. Different valid economic valuation of this wetland services might be helpful for sustainable management. In addition, many underlying causes those are potential for the depletion of ecosystem services like population pressure, land use change, over 
exploitation, climate change and water \& soil quality loss (Haque, 2012; Mamun et al., 2013; Nahar, 2013; Morshed, 2013). Nowadays, wetland services are highly vulnerable due to natural and anthropogenic causes and decreasing day by day (Nahar, 2013; Morshed, 2013). Several works have been conducted to present status of wetlands but researches on economic valuation are limited. Therefore, the research was conducted to i) observe the status of water quality of haor wetlands ii) assess the economic values of ecosystem services and iii) identify the driving forces responsible for changes in the wetland ecosystem using DPSIR (Drivers-pressuresstates-impacts-responses) framework.

\section{Materials and Methods}

\section{Study area}

The Tanguar haor wetland is located in the Sunamganj district of Bangladesh, lies in the northeastern part of the country adjacent to the Indian border at $25^{\circ} 05^{\prime}-$ $25^{\circ} 12^{\prime}$ North and $91^{\circ} 01^{\prime}-91^{\circ} 07^{\prime}$ East (Fig. 1). It covers an area of $100 \mathrm{~km}^{2}$ and supporting at least 60,000 populations of Dharmapasha and Tahirpur upazilla's. This wetland has been recognized as a wetland of global importance under the Ramsar agreement since 2000, and it has rich biodiversity. The haor consists of 120 beels of different sizes.

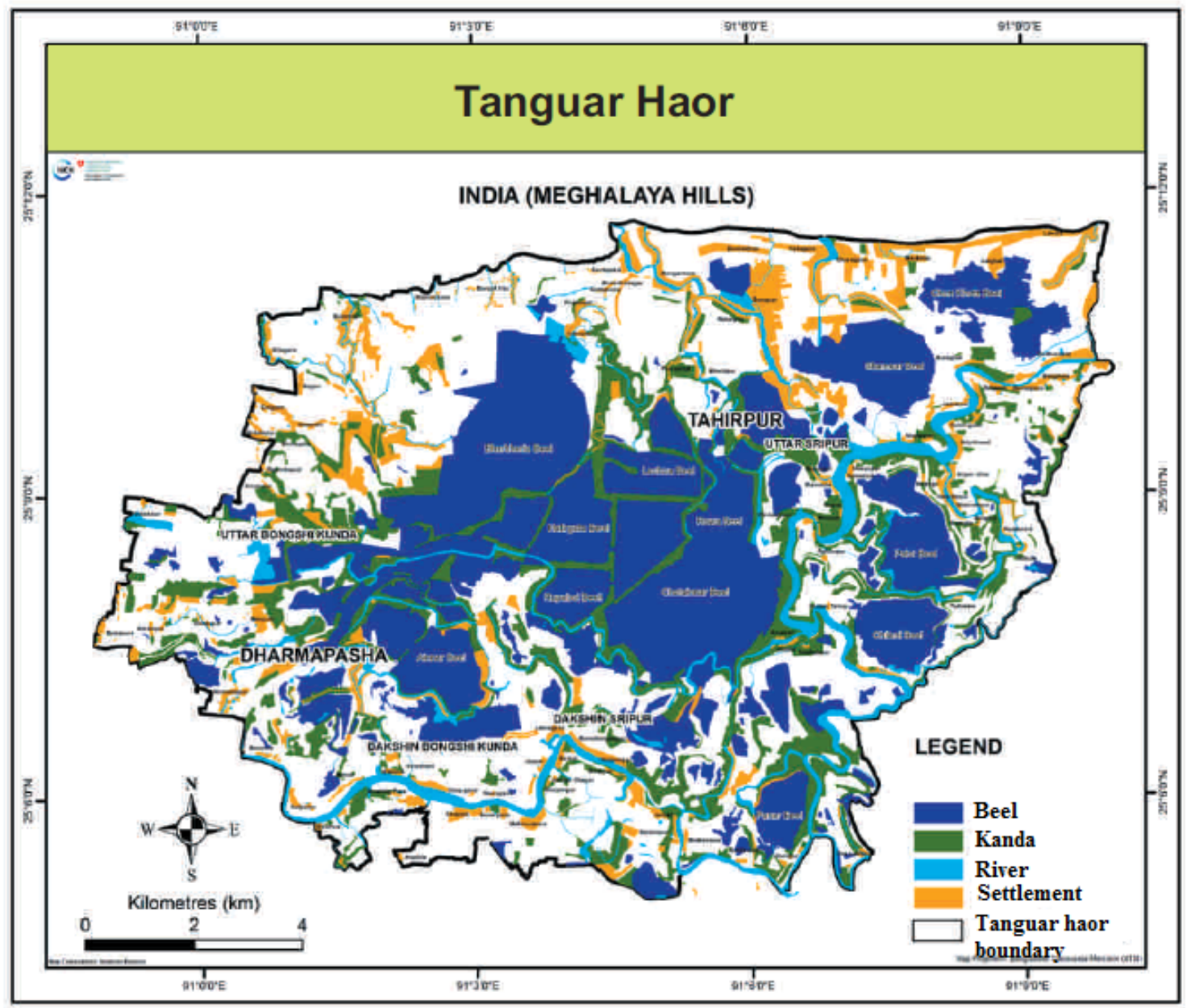

Fig. 1. Map of Tanguar haor wetland. (Source: IUCN, 2015)

\section{Data collection and analysis}

\section{Data sources}

Baseline surveys and preliminary discussion with communities were conducted for selection of study area. Literature review, baseline survey, checklists, preliminary discussion with communities, face to face questionnaires survey and FGDs were conducted from November, 2016 to September, 2017. Purposive sampling was conducted for data collection because Tanguar haor is a vast area and many people obtain different benefits from this haor. Negative responses were excluded from the calculations like residential who are not accepted paddy, migratory birds and fuel etc. and who didn't get health benefits. Secondary data has been collected from different journals, reports, research papers, websites, and government and non-government organizations.

\section{Water quality measurement}

The water samples were collected from five locations of Tanguar haor e.g. Rupaboi beel $\left(\mathrm{L}_{1}\right)$, Muinsakhali beel $\left(\mathrm{L}_{2}\right)$, Chatrar beel $\left(\mathrm{L}_{3}\right)$, Boddof beel $\left(\mathrm{L}_{4}\right)$, and Kolma beel $\left(\mathrm{L}_{5}\right)$, during November, 2016 to February, 2017. 
Water was collected in $100 \mathrm{ml}$ plastic bottles. Before collecting water, the bottles were cleaned and washed up with distilled water. $\mathrm{pH}$ was measured by digital pocket $\mathrm{pH}$ meter at the sampling site. Electrical conductivity (EC) was measured by digital EC (Model: 8033, Hanna) meter and temperature was measured by digital thermometer. Total dissolved solid (TDS) and dissolved oxygen (DO) were measured by digital portable pocket TDS (Model: HI9813-5) and DO (Model: H19143, Hanna) meters, respectively. On the other hands $\mathrm{NO}_{3}$ and $\mathrm{PO}_{4}$ were measured using spectrophotometer in department of Soil Science, Bangladesh Agricultural University, Bangladesh.

\section{Economic valuation of ecosystem services}

The market value method is one of the most direct ways to approximate the value of material production and services of the haor system (Li and Gao, 2016). People obtain different resources from Tanguar haor and those resources have its own market value. The formula ( $\mathrm{Li}$ and Gao, 2016) is given in detail as follows:

$$
\mathbf{V}_{\mathbf{P s}}=\sum_{i=1}^{n}(Q \mathbf{M i})
$$

Here, $V_{P s}$ is the value of provisioning ecosystem services (BDT). Qi is the quantity of obtained resource (Mon or $\mathrm{kg}$ or pieces) of type $\mathrm{i}$ services. $\mathrm{Mi}$ is the average market prices (BDT-Mon or $\mathrm{kg}$ or pieces) of type i material $(1 M o n=40 \mathrm{Kg})$.

Contingent value method is used to estimate the fiscal value of ecosystem services of the haor according to residential and tourist perceptions. This study used an open questionnaire and asked respondents to select their willingness to pay (WTP) ( $\mathrm{Li}$ and Gao, 2016).

\section{Impacts analysis}

To identify the relatively impacts on ecosystem by natural and anthropogenic causes, here we applied DPSIR (Driver - Pressure - State - Impact - Response) framework (EEA, 1999). The simplest matrices used to recognize the rate of impacts on ecosystem services due to anthropogenic and natural activities. The impacts are calculated as low, tolerable, medium, high and finally very high. Here a scale from 0 to 5 for impact magnitude used for giving score (scale: 0 - no observable effect; 1 - Low effect; 2 - Tolerable effect; 3 - Medium high effect; 4 - High effect; 5 - Very high effect).

\section{Results and Discussion}

\section{Water quality of Tanguar haor}

Water samples were collected from different locations of the Tanguar haor to observe the present water quality status (Table 1). The water temperature among all the sampling stations of Tanguar haor ranged from $27.2^{\circ} \mathrm{C}$ to $29.4^{\circ} \mathrm{C}$ with a mean value of $28.28^{\circ} \mathrm{C}$. Similar mean value of temperature $\left(27.98^{\circ} \mathrm{C}\right)$ was found by Mamun et al. (2013) from Tanguar haor water. Average $\mathrm{pH}$ of the water samples ranged from 7.3 to 8.7. Averages DO of the water sample ranged from $4.27 \mathrm{mg} \mathrm{L}^{-1}$ to $8.56 \mathrm{mg}$ $\mathrm{L}^{-1}$. But Mamun et al. (2013) found the highest DO value was $5.5 \mathrm{mg} \mathrm{L}^{-1}$ at Majampur and the lowest value was $4.5 \mathrm{mg} \mathrm{L}^{-1}$ at Hoirakuna. Normal TDS of the water samples ranged from 731 to $1020 \mathrm{mg} \mathrm{L}^{-1}$. The highest TDS value was $1036 \mathrm{mg} \mathrm{L}^{-1}$ at Lamagau beel and the lowest value was $670 \mathrm{mg} \mathrm{L}^{-1}$ at Lamagau (Mamun et al., 2013). The higher TDS value of water may be due to the high contents of dissolved ions in water that flows from upstream, nearby agricultural land and domestic materials. EC value measured at different sampling stations ranged from 1120 to $1460 \mu \mathrm{S} \mathrm{cm} \mathrm{cm}^{-1}$ with the mean value of $1231 \mu \mathrm{S} \mathrm{cm}^{-1}$. $\mathrm{NO}_{3}$ of the water samples ranged from 0.763 to $1.769 \mathrm{mg} \mathrm{L}^{-1}$. Islam et al. (2014) found the average $\mathrm{NO}_{3}$ value about $15.6 \mathrm{mg} \mathrm{L}^{-1}$ at Premonsoon (March-May) in Hakaluki haor. $\mathrm{PO}_{4}$ of the water samples ranged from 0.022 to $0.078 \mathrm{mg} \mathrm{L}^{-1}$. $\mathrm{PO}_{4}$ value was about $5.58 \mathrm{mg} \mathrm{L}^{-1}$ at pre-monsoon (MarchMay) in Hakaluki haor (Islam et al., 2014). It is apparent from the above value of water sample, that the water was suitable for fish production and other aquatic organisms at Tanguar haor wetland.

Table 1. Status of water quality parameters at different beels of Tanguar haor wetland

\begin{tabular}{|c|c|c|c|c|c|c|c|}
\hline Parameters & $\begin{array}{c}\text { Rupaboi } \\
\text { Beel }\end{array}$ & $\begin{array}{c}\text { Muinsakhali } \\
\text { Beel }\end{array}$ & $\begin{array}{c}\text { Choatrar } \\
\text { Beel } \\
\end{array}$ & $\begin{array}{c}\text { Boddof } \\
\text { Beel }\end{array}$ & $\begin{array}{c}\text { Kolma } \\
\text { Beel }\end{array}$ & Mean & $\begin{array}{r}\text { Standard } \\
\text { Deviation }\end{array}$ \\
\hline Temperature $(\mathrm{C})$ & 27.2 & 27.6 & 29.2 & 29.4 & 27.9 & 28.26 & 0.98 \\
\hline $\mathrm{pH}$ & 7.5 & 8.7 & 7.5 & 7.6 & 7.3 & 7.72 & 0.56 \\
\hline $\operatorname{TDS}\left(\mathrm{mg} \mathrm{L}^{-1}\right)$ & 1020 & 981 & 805 & 988 & 731 & 905 & 128.6 \\
\hline $\mathrm{EC}\left(\mu \mathrm{S} \mathrm{cm}^{-1}\right)$ & 1070 & 1255 & 1460 & 1120 & 1250 & 1231 & 7.14 \\
\hline $\mathrm{DO}\left(\mathrm{mg} \mathrm{L}^{-1}\right)$ & 8.56 & 4.27 & 4.67 & 5.18 & 7.18 & 5.57 & 1.83 \\
\hline $\mathrm{NO}_{3}\left(\mathrm{mg} \mathrm{L}^{-1}\right)$ & 0.763 & 1.153 & 1.339 & 0.962 & 1.769 & 1.2 & 0.38 \\
\hline $\mathrm{PO}_{4}\left(\mathrm{mg} \mathrm{L}^{-1}\right)$ & 0.043 & 0.052 & 0.035 & 0.022 & 0.078 & 0.05 & 0.02 \\
\hline
\end{tabular}

Demographic characteristics of the residential and tourist respondents: Mainly young and adult married male peoples accepted the ecosystem services from Tanguar haor. The educational level was very low in this region due to insufficient educational institution, communication and finally economical status. Fishermen and boatmen were the highest percentage profession among the respondents. Fisherman catch fish and boatman engaged with driving boat all over the year. This may be because of high opportunities and availability of fish and availability of tourists. More than fifty percent respondent income was 12001-20000 BDT month $^{-1}$. Most important occupation near Tanguar haor area is farming, fishing, handicraft, small business and 
livestock husbandry while $41.7 \%$ household involved with fishing and $36.3 \%$ with farming (IUCN, 2015). Most of the tourists were male and married. But they were young and most of them were student and the reason behind that young married person and students are more interested to visit Tanguar haor for refreshment and educational purposes. The majority tourist's income level were $>40000$ BDT month ${ }^{-1}$. Most of the residential respondents had no knowledge about ecosystem services. This is occurred due to low educational background. Approximately, fifty percent of the tourists were familiar with ecosystem services.

\section{Respondent's perception about ecosystem services}

The most commonly used and obtained ecosystem services by the residential inhabitant's were provisioning, regulatory, cultural and supporting services (Table 2). Amongst 120 residential respondents, eighty three (83) never heard about ecosystem services before. On the other hand, 26 tourists were familiared with ES services first time. According to residential respondents, "provisioning" services were highly accepted and valuable services among four ecosystem services of Tanguar haor wetland whereas regulatory" services were least accepted and prioritized services. This is due to the difficulty of accept, less knowledge and valuation problem. But tourist respondents accept cultural services mostly with a little provisioning service. Overall change of ecosystem service was identified by residential respondents, where "provisioning" and "supporting" services have been decreasing from last 10 years (Fig. 1). But according to tourists "provisioning" and "regulatory" services have been decreasing from last 10 years due to environmental changes, natural hazards, settlement, and mismanagement of biodiversities with over exploitation (Uddin et al., 2015; Haque and Basak, 2017).

On the other hand tourist perceived that they have no knowledge about supporting services changes due to the coming from far distance and have negligible knowledge about supporting services (Bhandari et al., 2016). Land use policies, land use planning, population growth mismanagement of biodiversity were responsible for decreasing Tanguar haor wetland services (Liu et al., 2012; Sun et al., 2017).

Table 2. Lists of utilized ES by the respondents

\begin{tabular}{ll}
\hline \multicolumn{1}{c}{ Ecosystem Services } & \multicolumn{1}{c}{ Examples } \\
\hline Provisioning & $\begin{array}{l}\text { Paddy, vegetables, fuel, biochemical's \& natural medicines, genetic resources, fresh water, } \\
\text { fodder, shade and shelter, fish production and migratory birds }\end{array}$ \\
& Climate regulation, carbon sequestration, water purification, natural hazards regulation, water \\
& regulation, waste treatment, pollination, soil fertility maintenance \\
Regulatory & inspiration for art, folklore, social relations, aesthetic values, cultural heritage values, recreation \\
& \& tourism, health benefit, knowledge, sense of place \\
Cultural & Soil formation and retention, nutrient cycling, primary production, water cycling, provision of \\
hupporting & habitat, habitats for species, photosynthesis \\
\hline
\end{tabular}

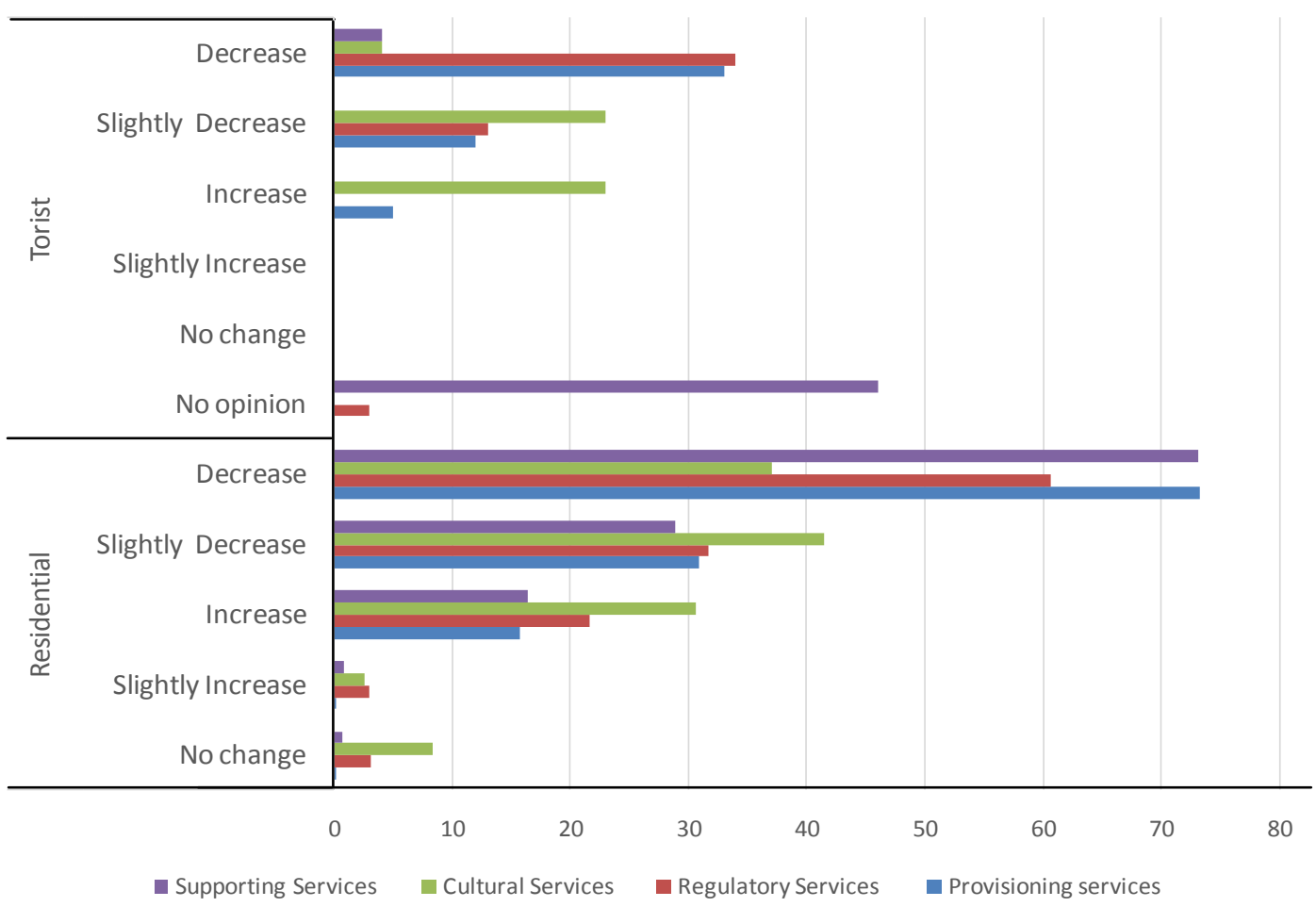

Fig. 1. Changes of ecosystem services during last 10 years at Tanguar haor 
Economic valuations of ES

Total economic value of ecosystem services from Tanguar haor wetland estimated was 174039980 BDT year $^{-1}$ (Table 3). But total annual benefit from Tanguar haor was estimated as BDT 1.59 billion or USD 20.46 million (Haque et al., 2012). This is partially similar with our findings because of the author calculation was based on individual services but we examined only 120 respondents and all services together. World Conservation Union (IUCN) has estimated that the economic value of Hakaluki haor was BDT 585.75 year ${ }^{-1}$ (IUCN, 2006).

Table 3. Monetary value of the Tanguar haor wetland ecosystem services

\begin{tabular}{lcc}
\hline Ecosystem service & $\begin{array}{c}\text { Valuation } \\
\text { Methods }\end{array}$ & $\begin{array}{c}\text { Amount of resources } \\
\text { (BDT year }\end{array}$ \\
\hline Provisioning (10) & MVM and CVM & 171850980 \\
Regulatory (8) & CVM & 480700 \\
Cultural (8) & CVM & 570900 \\
Supporting (7) & CVM & 914900 \\
& Total (33) & 173817480 \\
Tourists perceived & CVM & 222500 \\
economic value of & & \\
cultural services (6) & & \\
& Total (39) & 174039980BDT year $^{-1}$ \\
\hline
\end{tabular}

Detailed break-up of monetary value from provisioning ecosystem has been in Table 4. Economic value of paddy, vegetables, fuel, fodder, fish and migratory birds were calculated by equation no (1) using MVM. Economic values of all provisioning services from Tanguar haor were 171850980 BDT year $^{-1}$ while per person value calculated as 1432091.5 BDT year ${ }^{-1}$.

"Mismanagement of biodiversity" was highly responsible factor for depleting ES of Tanguar haor. Whereas second top prioritize factor was given to "sedimentation of haor" (Fig. 2). Impact matrix was calculated and provisioning services had the highest effects and its impact factor was 4.85. Mismanagement of biodiversity and climate change had very high potentiality to deplete ecosystem services of Tanguar haor wetland. Final impact factor was found 4.16 by cross relation between ecosystem services and its depleting factors (natural and anthropogenic).

Table 4. Monetary value of provisioning ecosystem services from Tanguar haor wetland

\begin{tabular}{|c|c|c|c|c|}
\hline Provisioning services & $\begin{array}{c}\text { Quantity of collected } \\
\text { resource }\end{array}$ & $\begin{array}{c}\text { Market price /Mon } \\
\text { or Kg }\end{array}$ & $\begin{array}{c}\text { Valuation } \\
\text { method }\end{array}$ & $\begin{array}{c}\text { Cost of resources (BDT } \\
\text { year }^{-1} \text { ) }\end{array}$ \\
\hline Paddy & 13840 Mon year $^{-1}$ & $1000 \mathrm{BDT}$ & MVM & 13840000 \\
\hline Vegetables & $41040 \mathrm{Kg}$ year $^{-1}$ & $20 \mathrm{BDT}$ & MVM & 820800 \\
\hline Fuel & 2614 Mon year $^{-1}$ & $120 \mathrm{BDT}$ & MVM & 313680 \\
\hline Fodder & $338760 \mathrm{Kg}$ year $^{-1}$ & $15 \mathrm{BDT}$ & MVM & 5081400 \\
\hline Fish & $755640 \mathrm{Kg}$ year $^{-1}$ & $200 \mathrm{BDT}$ & MVM & 151128000 \\
\hline Migratory birds & 2345 Pieces year $^{-1}$ & $250 \mathrm{BDT}$ & MVM & 586250 \\
\hline $\begin{array}{l}\text { Biochemical's\& natural } \\
\text { medicines }\end{array}$ & - & - & CVM & 25630 \\
\hline Genetic resources & - & - & CVM & 17580 \\
\hline Fresh water & - & - & CVM & 24240 \\
\hline \multirow[t]{2}{*}{ Shade and shelter } & - & - & CVM & 13400 \\
\hline & & & Total & 171850980 BDT year $^{-1}$ \\
\hline
\end{tabular}

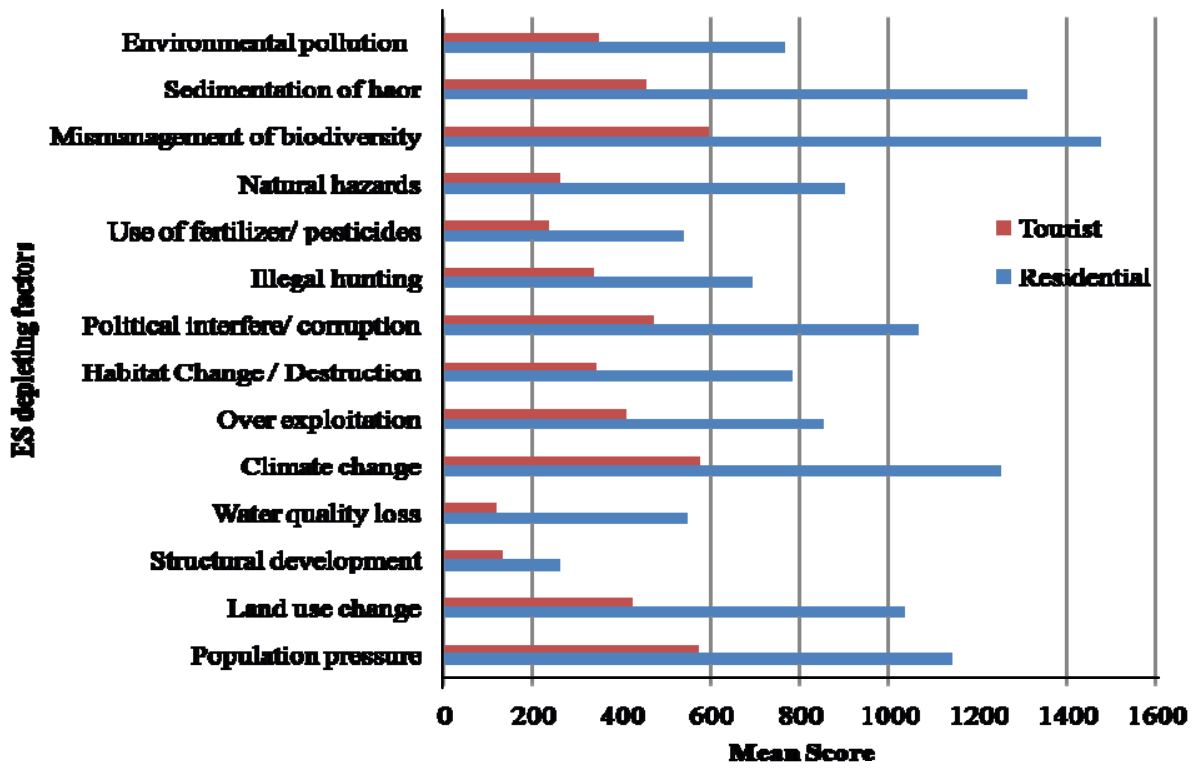

Fig. 2. Perception about depletion of ecosystem services in Tanguar haor 
Ecosystem services within the DPSIR framework

Most common driving forces observed as demographic, population, economic, cultural factors and land based activities. Pressures and states detected as climate change, natural hazards, land use changes and soil \& water pollution, sedimentation and changes of ecosystem services, respectively. Serious impacts was found as environmental \& economic impacts, loss of water resources, fewer habitats for fishes and birds, migration, extinction of species and opportunities of livelihoods activities etc. These common impacts has the potentially to destroy the ecological status of Tanguar haor as well as ecosystem services near future. The possible impacts from human and natural activities on wetland such as over-exploitation, habitat loss and fragmentation, pollution, climate change, agricultural land loss and the spread of invasive alien species (Haque, 2012; Nahar, 2013; Morshed, 2013).

Human responses against these changes have included integrated wetland management, sustainable use of resources, afforestation, alternative livelihoods and voluntary agreements and so on (Fig. 3). Nowadays it is apparent that wetland faced severe impacts in spite of different activities by various organizations. So it's urgent to take actual steps for protection of wetland services like haor management laws \& policy, more afforestation, penalty for over hunting \& use of haor resources, natural vegetation and encourage conservation practices.

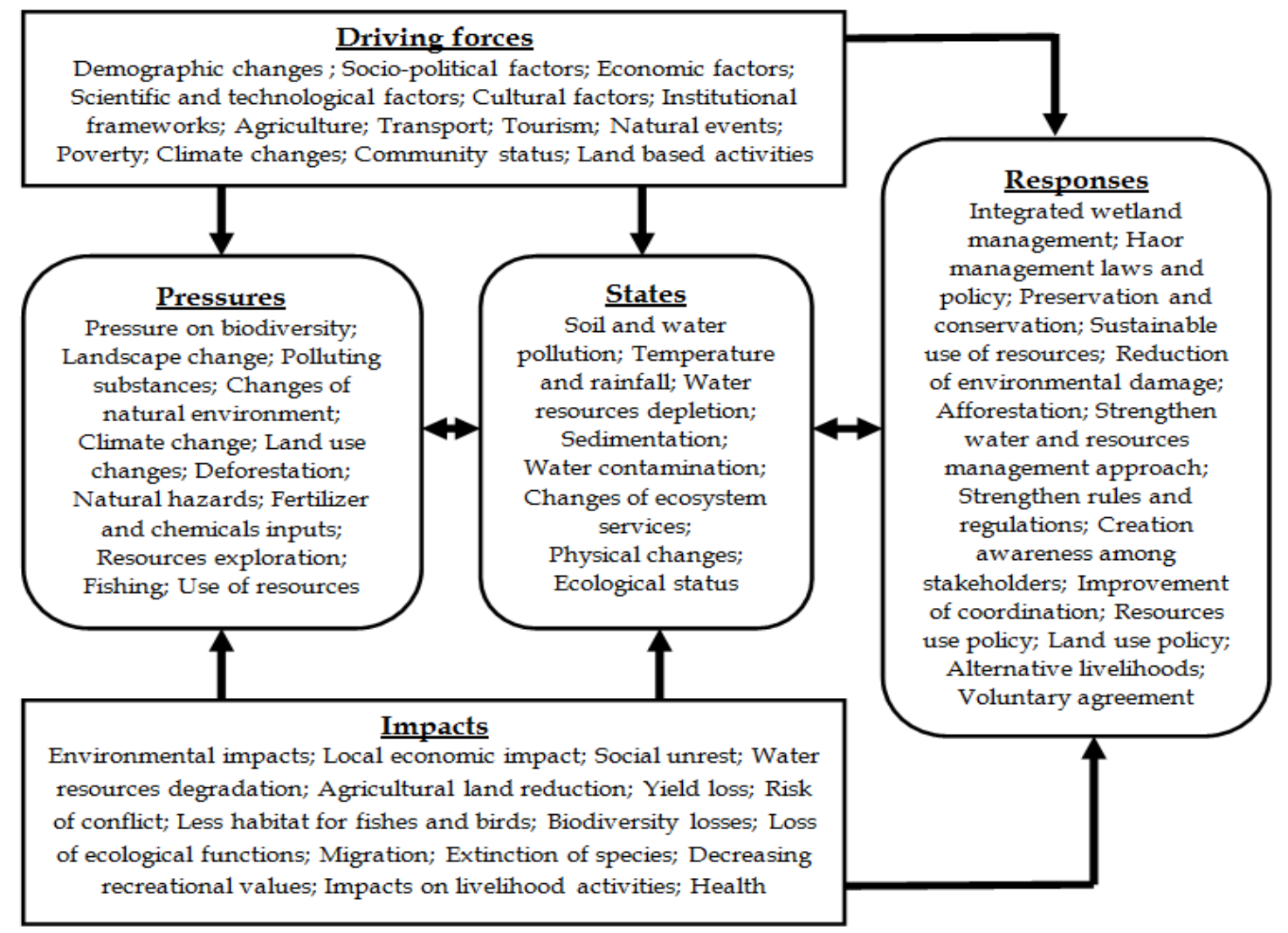

Fig. 3. Impacts and changes of ecosystem services: DPSIR framework.

\section{Conclusion}

Although the residential respondents had no knowledge about ecosystem services, four types of ecosystem services such as provisioning, regulatory, cultural and supporting were received by the residential respondents from the Tanguar haor. Different scenarios were observed for the tourists and they accept mainly cultural services. Total economic value of ecosystem services of Tanguar haor estimated at 173817480 BDT year ${ }^{-1}$ whereas tourists perceived economic values of cultural services estimated at $4450 \mathrm{BDT}_{\text {year }}{ }^{-1}$ tourist $^{-1}$. Impact factor among ecosystem services was identified and its depleting factors were identified as 4.16. On the contrary, by applying DPSIR framework, identified impacts were environmental and economic impacts, loss of water resources, fewer habitats for fishes and birds, extinction of species and opportunities of livelihoods activities etc. Probable responses by communities were identified as sustainable use of resources, afforestation, alternative livelihoods, raising awareness and apply conservation techniques. Mismanagement of biodiversity was the highly responsible underlying factor for depleting ecosystem services at Tanguar haor. But over exploitation, sedimentation of haor, climate change, illegal hunting, land use changes and habitat changes also responsible for depleting these services. This study indicates that Tanguar haor has pivotal importance not only for human well being but also local and national 
economy as well as biodiversity and environment. In brief, this research work analyzed the possibility of vast amount of economic value from Tanguar haor wetland as well as provided a clear direction of sustainable management of ecosystem services by identifying the possible impacts and pressure.

\section{References}

Barbier, E.B. 2011. Wetlands as natural assets. Hydrological Sciences Journal, 56(8): 1360-1373.

Barbier, E.B., Acreman, M.C. and Knowler, D. 1997. Economic valuation of wetlands: a guide for policy makers and planners. Gland, Switzerland: Ramsar Convention Bureau.

Bhandari, P., Mohan, K.C., Shrestha, S., Aryal, A. and Shrestha, U.B. 2016. Assessments of ecosystem service indicators and stakeholder's willingness to pay for selected ecosystem services in the Chure region of Nepal. Applied Geography, 69: 25-34.

Costanz, R., d'Arge, R., Groot, D.R., Farber, S., Grasso, M., Hannon, B., Limburg, K., Naeem, S., O’Neill, R.V., Paruelo, J., Raskin, R.G., Sutton, P. and Belt, V.D.M. 1997. The value of the world's ecosystem services and natural capital. Nature, 387: 253-260.

EEA (European Environmental Agency) 1999. Environmental indicators: typology and overview. Copenhagen, European Environmental Agency. Technical report.

Fisher, B., Turner, R.K. and Morling, P. 2009. Defining and classifying ecosystem services for decision making. Ecological Economics, 68: 643-653.

Groot, D.R.S., Wilson, M.A. and Boumans, R.M.J. 2002. A typology for the classification, description and valuation of ecosystem services function, goods and services. Ecological Economics, 41: 393-408.

Haque, M.E. 2012. A study on wetland biodiversity of Kishoreganj district and its impact on environment, MS Thesis, Department of Environmental Science, Bangladesh Agricultural University, Mymensingh.

Haque, M.I., and Basak, R. 2017. Land cover change detection using GIS and remote sensing techniques: A spatio-temporal study on Tanguar haor, Sunamganj, Bangladesh. The Egyptian Journal of Remote Sensing and Space Sciences,20(2): 251-263.

Haque A.K.E., Shahzia M.K. and Diyan, M.A.A. 2012: Economic values and ecosystem services of Tanguar haor. Community Based Sustainable Management of Tanguar haor Project. IUCN, Dhaka, Bangladesh. pp. 42.

Islam, M.T., Rahman, M.M. and Mahmud, H. 2014. Physico-chemical attributes of water of Hakaluki Haor, Sylhet, Bangladesh. Jahangirnagar University Journal of Biological Science, 3(2): $67-72$.
IUCN (International Union for Conservation of Nature) 2006. Final report: Natural resource economic evaluation of Hakalukihaor. Prepared and submitted by The World Conservation Union Bangladesh office in association with Center for Natural Resource Studies (CNRS) for Ministry of Environment and Forests (MoEF), Dhaka, Bangladesh.

IUCN (International Union for Conservation of Nature) 2015. Tanguar haor management plan framework and guidelines. IUCN Bangladesh, Country Office, Dhaka, Bangladesh.

Kabir, M.H., and Amin, S.M.N. 2006. Socioeconomic assessments of the local people at Tanguar haor (wetland), Bangladesh a geographical analysis. Oriental Geographer, 50(2): 67-83.

Khan, A.A. 1993. Freshwater wetlands in Bangladesh: Opportunities and options, in freshwater wetlands in Bangladesh. Issues and approaches for management, The World Conservation Union, Dhaka Bangladesh. pp. 01-08.

Li, T., and Gao, X. 2016. Ecosystem services valuation of lake side wetland park beside ChaohuLakein China. Water, 8: 301.

Liu, Y., Li, J. and Zhang, H. 2012. An ecosystem service valuation of land use change in Taiyuan city, China. Ecological Modelling, 225: 127-132.

Mamun, S.A., Roy, S., Rahaman, M.S., Jahan, and Islam, M.S. 2013. Status of fisheries resources and water quality of Tanguar haor. Journal of Environmental Science \& Natural Resources, 6: 103-106.

MEA (Millennium Ecosystem Assessment) 2005.Ecosystems and human well-being: wetlands and water synthesis. World Resources Institute, Washington, DC.

Morshed, M.N. 2013. Biodiversity of some selected areas of Tanguar haor, MS Thesis, Department of Environmental Science, Bangladesh Agricultural University, Mymensingh.

Nahar, T. 2013. Biodiversity of some selected haor areas in Kishoreganj district, MS Thesis, Department of Environmental Science, Bangladesh Agricultural University, Mymensingh.

RCS (Ramsar Convention Secretariat) 2013. The Ramsar convention manual: a guide to the convention on wetlands (Ramsar, Iran, 1971), 6th ed. Ramsar Convention Secretariat, Gland, Switzerland.

Sun, C., Zhen, L. and Miah, M.G. 2017. Comparison of the ecosystem services provided by China's Poyang Lake wetland and Bangladesh's Tanguar haor wetland. Ecosystem Services, 26: 411-421.

TEEB (Economics of Ecosystems and Biodiversity) 2010. The Economics of Ecosystems and Biodiversity ecological and economic foundations. Earthscan, London and Washington.

Uddin, M.R., Miah, M.G.U., Afrad, M.S.I., Mehraj, H. and Mandal, M.S.H. 2015. Land use change and its impact on ecosystem services, livelihood in Tanguar haor wetland of Bangladesh. Scientia Agriculturae, 12(2): 78-88. 